\title{
Preclinical In Vitro and In Vivo Evaluation of $\left[{ }^{18}\right.$ F]FE@SUPPY for Cancer PET Imaging: Limitations of a Xenograft Model for Colorectal Cancer
}

\author{
T. Balber, ${ }^{1,2}$ J. Singer, ${ }^{1,3,4}$ N. Berroterán-Infante, ${ }^{1}$ M. Dumanic, ${ }^{1}$ \\ L. Fetty, ${ }^{1,5}$ J. Fazekas-Singer $\mathbb{D}^{3},{ }^{3,6}$ C. Vraka, ${ }^{1}$ L. Nics, ${ }^{1,7}$ M. Bergmann, ${ }^{8}$ K. Pallitsch, ${ }^{9}$ \\ H. Spreitzer, ${ }^{10}$ W. Wadsak ${ }^{1 D},{ }^{1,11}$ M. Hacker, ${ }^{1}$ E. Jensen-Jarolim, ${ }^{3,6}$ \\ H. Viernstein, ${ }^{2}$ and M. Mitterhauser $\mathbb{D}^{1,12}$ \\ ${ }^{1}$ Biomedical Imaging and Image-Guided Therapy, Division of Nuclear Medicine, Medical University of Vienna, \\ Vienna, Austria \\ ${ }^{2}$ Department of Pharmaceutical Technology and Biopharmaceutics, Faculty of Life Sciences, University of Vienna, \\ Vienna, Austria \\ ${ }^{3}$ Institute of Pathophysiology and Allergy Research, Center of Pathophysiology, Infectiology and Immunology, \\ Medical University of Vienna, Vienna, Austria \\ ${ }^{4}$ Department of Internal Medicine II, University Hospital Krems, Karl Landsteiner University of Health Sciences, \\ Krems an der Donau, Austria \\ ${ }^{5}$ Department of Radiation Oncology, Division of Medical Physics, Medical University of Vienna, Vienna, Austria \\ ${ }^{6}$ Comparative Medicine, The Interuniversity Messerli Research Institute, The University of Veterinary Medicine Vienna, \\ Medical University of Vienna, and University of Vienna, Vienna, Austria \\ ${ }^{7}$ Department of Nutritional Sciences, Faculty of Life Sciences, University of Vienna, Vienna, Austria \\ ${ }^{8}$ Department of Surgery, Surgical Research Laboratories, Medical University of Vienna, Vienna, Austria \\ ${ }^{9}$ Institute of Organic Chemistry, University of Vienna, Vienna, Austria \\ ${ }^{10}$ Department of Pharmaceutical Chemistry, Faculty of Life Sciences, University of Vienna, Vienna, Austria \\ ${ }^{11} \mathrm{CBmed}$ GmbH, Graz, Austria \\ ${ }^{12}$ Ludwig Boltzmann Institute Applied Diagnostics, Vienna, Austria
}

Correspondence should be addressed to M. Mitterhauser; markus.mitterhauser@meduniwien.ac.at

Received 23 November 2017; Accepted 27 December 2017; Published 13 February 2018

Academic Editor: Giorgio Biasiotto

Copyright (C) 2018 T. Balber et al. This is an open access article distributed under the Creative Commons Attribution License, which permits unrestricted use, distribution, and reproduction in any medium, provided the original work is properly cited.

Molecular imaging probes such as PET-tracers have the potential to improve the accuracy of tumor characterization by directly visualizing the biochemical situation. Thus, molecular changes can be detected early before morphological manifestation. The $\mathrm{A}_{3}$ adenosine receptor $\left(\mathrm{A}_{3} \mathrm{AR}\right)$ is described to be highly expressed in colon cancer cell lines and human colorectal cancer (CRC), suggesting this receptor as a tumor marker. The aim of this preclinical study was the evaluation of $\left[{ }^{18} \mathrm{~F}\right] \mathrm{FE} @ \mathrm{SUPPY}$ as a PET-tracer for CRC using in vitro imaging and in vivo PET imaging. First, affinity and selectivity of FE@SUPPY and its metabolites were determined, proving the favorable binding profile of FE@SUPPY. The human adenocarcinoma cell line HT-29 was characterized regarding its $\mathrm{hA}_{3} \mathrm{AR}$ expression and was subsequently chosen as tumor graft. Promising results regarding the potential of $\left[{ }^{18} \mathrm{~F}\right] \mathrm{FE} @ S U P P Y$ as a PET-tracer for CRC imaging were obtained by autoradiography as $\geq 2.3$-fold higher accumulation of $\left[{ }^{18} \mathrm{~F}\right] \mathrm{FE} @ S U P P Y$ was found in CRC tissue compared to adjacent healthy colon tissue from the same patient. Nevertheless, first in vivo studies using HT-29 xenografts showed insufficient tumor uptake due to (1) poor conservation of target expression in xenografts and (2) unfavorable pharmacokinetics of $\left[{ }^{18} \mathrm{~F}\right] \mathrm{FE} @ S U P P Y$ in mice. We therefore conclude that HT-29 xenografts are not adequate to visualize $\mathrm{hA} \mathrm{A}_{3} \mathrm{ARs}$ using $\left[{ }^{18} \mathrm{~F}\right] \mathrm{FE} @ S U P P Y$. 


\section{Introduction}

Colorectal cancer (CRC) is the fourth leading cause of cancer-related deaths in men and women worldwide [1]. The primary diagnosis is usually made by colonoscopy and biopsy, which often does not reflect the full extent of the disease due to tumor heterogeneity and disregard of potential metastases. Positron Emission Tomography (PET) provides a noninvasive imaging technique, which is valuable for tumor staging and clinical decision making and to estimate the patient's prognosis [2]. Besides the routinely used PET-tracer $\left[{ }^{18} \mathrm{~F}\right]$ FDG, the availability of specific tumor tracers would enhance the characterization of colorectal tumors and help in CRC staging and with the choice of treatment.

An essential characteristic of most solid tumors is hypoxia, which inevitably leads to accumulation of adenosine within the tumor microenvironment as a result of the breakdown of adenine nucleotides, which has been recognized in the 1990s [3, 4]. Since then, many efforts have been made to clarify the role of adenosine and its receptors in cancer [5-7]. The expression of the $A_{3}$ adenosine receptor $\left(A_{3} A R\right)$, which is one of four subtypes of the adenosine receptor family, has been reported in several human tumor cell lines including leukemia (Jurkat T, HL-60), melanoma (A375), and astrocytoma $(\mathrm{ADF})$ [8-12]. In particular, there is a rising interest in the involvement of $\mathrm{A}_{3} \mathrm{ARs}$ in $\mathrm{CRC}$ as $\mathrm{A}_{3} \mathrm{AR}$ protein expression has been reported for various colon cancer cell lines, including Caco-2, HCT-116, CCL-228, DLD-1, and HT29 [13-15]. Merighi et al. have shown that caffeine leads to hypoxia-inducible factor-1 (HIF-1) protein accumulation and increased vascular endothelial growth factor (VEGF) expression through $\mathrm{A}_{3} \mathrm{AR}$ stimulation in HT-29 cells under hypoxic conditions [16]. According to Sakowicz-Burkiewicz et al., treatment with the $\mathrm{A}_{3} \mathrm{AR}$ agonist IB-MECA $(1 \mu \mathrm{M})$ results in an $\mathrm{A}_{3} \mathrm{AR}$-dependent growth promoting effect in HT-29 cells. In contrast, IB-MECA causes cell apoptosis in HCT-116 cells, similarly in an $\mathrm{A}_{3} \mathrm{AR}$ dependent manner [13].

High expression of $\mathrm{A}_{3} \mathrm{AR}$ mRNA and protein has been reported in colon and breast carcinoma compared to adjacent nonneoplastic tissue by Madi et al. Remarkably, even higher levels of $\mathrm{A}_{3} \mathrm{AR}$ mRNA have been found in lymph node metastases than in primary tumor tissue, suggesting $\mathrm{A}_{3} \mathrm{AR}$-overexpression as a marker for tumor progression [17]. Additionally, Gessi et al. studied $\mathrm{A}_{3} \mathrm{AR}$ expression in colorectal cancer tissue samples of 73 patients and provided evidence that the $A_{3} A R$ has the potential to be used as a diagnostic marker for colon cancer. The authors have shown $\geq 2$-fold increased $\mathrm{A}_{3} \mathrm{AR}$ protein expression in primary colon carcinomas compared to normal mucosa and describe a tendency towards higher $\mathrm{A}_{3} \mathrm{AR}$ expression in large adenomas compared to small adenomas. Therefore, the authors proposed a major role of the $\mathrm{A}_{3} \mathrm{AR}$ in cancer aggressiveness [18]. Moreover, radioligand binding experiments using the $\mathrm{A}_{3} \mathrm{AR}$ antagonist $\left[{ }^{3} \mathrm{H}\right] \mathrm{MRE} 3008 \mathrm{~F} 20$ and western blot analysis indicated that the $A_{3} A R$ is the most abundant of all four adenosine receptor subtypes in colorectal cancer tissues as well as in colon cancer cell lines (Caco-2, DLD-1 and HT29). On the contrary, RT-PCR experiments showed relatively low levels of $A_{3} A R$ mRNA in the mentioned colon cancer cell lines compared to mRNA levels of the other adenosine receptor subtypes [15]. As mRNA levels do not necessarily correlate with protein levels [19] and protein transcription is a prerequisite for targeted receptor imaging approaches such as PET imaging, protein expression data is the most relevant for this study.

The $\mathrm{A}_{3} \mathrm{AR}$ antagonist $\left[{ }^{18} \mathrm{~F}\right] \mathrm{FE} @ S U P P Y$ has been presented as the first PET-tracer for $\mathrm{hA}_{3} \mathrm{AR}$ imaging in 2008 by Wadsak et al. [20, 21]. First preclinical PET imaging using CHO-K1-hA $\mathrm{A}_{3} \mathrm{AR}$ xenografts has shown promising results leading to further evaluation of this PET-tracer in oncology [22]. Besides $\left[{ }^{18} \mathrm{~F}\right] \mathrm{FE} @ S U P P Y$ and $\left[{ }^{18} \mathrm{~F}\right] \mathrm{FE} @ S U P P Y: 2$, only a few other PET-ligands have been proposed for $A_{3} A R$ imaging, including carbon-11 labeled 1,2,4-triazolo[4,3a]quinoxalin-1-one derivatives and bromine-76 labeled nucleoside ligands ( $\left[{ }^{76} \mathrm{Br}\right] \mathrm{MRS} 3581$ and $\left.\left[{ }^{76} \mathrm{Br}\right] \mathrm{MRS} 5147\right)$ [23-25]. To our knowledge, no preclinical in vivo PET imaging has been reported for these $\mathrm{A}_{3} \mathrm{AR}$ PET-ligands so far. In our preclinical study, we aimed to evaluate $\left[{ }^{18} \mathrm{~F}\right] \mathrm{FE} @ S U P P Y$ as a PET-tracer for human cancer using in vitro imaging and in vivo PET imaging in a CRC tumor model.

\section{Methods}

\subsection{General}

2.1.1. Cell Culture. HT-29 cells and CHO-K1 cells were purchased from ATCC. HT-29 cells were cultured in RPMI 1640 medium supplemented with $10 \%$ fetal calf serum, $2 \mathrm{mM}$ L-glutamine, and $10 \mu \mathrm{g} / \mathrm{mL}$ gentamicin sulfate. Human $\mathrm{A}_{3}$ adenosine receptor-expressing $\mathrm{CHO}-\mathrm{K} 1$ cells (CHO-K1$\mathrm{hA}_{3} \mathrm{AR}$ ) were purchased from PerkinElmer (ValiScreen ${ }^{\circledR}$ GPCR cell line) and were grown using Ham's F12 supplemented with $10 \%$ FCS, $2 \mathrm{mM}$ L-glutamine, penicillin $(100 \mathrm{U} / \mathrm{M})$, streptomycin $(100 \mu \mathrm{g} / \mathrm{mL})$, and $0.4 \mathrm{mg} / \mathrm{mL}$ G418. Parental CHO-K1 cells were cultured likewise, but without selection antibiotics. Cells were maintained under standard conditions in a humidified incubator $\left(37^{\circ} \mathrm{C}, 5 \% \mathrm{CO}_{2}\right)$.

2.1.2. Animals. Six-week-old male BALB/c mice (BALB/ cAnNRj, Division of Laboratory Animal Science and Genetics, Himberg, Austria) were kept under conventional housing conditions, with food and water supply ad libitum and a $12 \mathrm{~h}$ day/night cycle. Male, immunodeficient CB17-SCID mice (CB-17/Icr-Prkdc $c^{\mathrm{scid}} / \mathrm{Rj}$, Janvier Labs, France) of the same age were kept under specific pathogen-free conditions in individually ventilated cages. All animals were treated according to the European Union rules on animal care. The corresponding animal experiments were approved by the Austrian Ministry of Sciences (BMWFW-66.009/0031WF/V/3b/2015, BMWFW-66.009/0029-WF/V/3b/2015).

2.1.3. Tumor Grafting. After 10 to 14 days upon arrival, CB17SCID mice were injected subcutaneously with $2 \times 10^{6} \mathrm{HT}$ 29 cells into one flank and $2 \times 10^{6} \mathrm{CHO}-\mathrm{K} 1$ cells in the opposite flank $(n=9)$. Body weight and tumor development 
were monitored every second day by caliper measurement. The respective tumor volume was calculated according to the following equation: tumor volume $\left(\mathrm{mm}^{3}\right)=d^{2} \times D / 2$ (where $d$ is the shortest diameter and $D$ the longest diameter). Animals were subjected to $\mu \mathrm{PET}$ imaging 10 days after inoculation, when tumors reached a volume of at least $300 \mathrm{~mm}^{3}$. Tumor volume never exceeded $1 \mathrm{~cm}^{3}$.

2.1.4. Human Tissues. Colorectal carcinoma tissue and adjacent healthy colon tissue were obtained directly after tumorectomy from two patients after full informed consent and quick-frozen in 2-methylbutane $\left(-40^{\circ} \mathrm{C}\right)$. Tissue was sliced into $16 \mu \mathrm{m}$ slices using a microcryotome (Thermo Scientific Microm HM 560) and stored at $-80^{\circ} \mathrm{C}$ until usage. Depending on the sample size, 3 to 4 different regions were defined and analyzed by means of autoradiography and immunohistochemistry.

\subsection{Characterization of Binding and Target Expression}

2.2.1. Competitive Binding Assay. Competitive binding assays were performed using $\mathrm{hA}_{1} \mathrm{AR}, \mathrm{hA}_{2 \mathrm{~A}} \mathrm{AR}$, or $\mathrm{hA} \mathrm{A}_{3} \mathrm{AR}$ expressing cell membranes $(18.5 \mathrm{ng} / \mu \mathrm{L}, 16.7 \mathrm{ng} / \mu \mathrm{L}$, or $1.7 \mathrm{ng} / \mu \mathrm{L}$ final protein concentration, resp.) and $1.7 \mathrm{nM}\left[{ }^{3} \mathrm{H}\right] \mathrm{DPCPX}$ $\left(K_{D}=1.7 \mathrm{nM}\right), 50 \mathrm{nM}\left[{ }^{3} \mathrm{H}\right] \mathrm{CGS} 21680\left(K_{D}=23 \mathrm{nM}\right)$, or $0.4 \mathrm{nM}\left[{ }^{125} \mathrm{I}\right] \mathrm{AB}-\mathrm{MECA}\left(K_{D}=0.78 \mathrm{nM}\right)$ as the respective radioligands (all purchased from PerkinElmer, Inc. Waltham, USA). The assay was performed according to the manufacturer's instructions in a final volume of $500 \mu \mathrm{L}$. Increasing concentrations of test compounds were added, whereby the concentration of dimethyl sulfoxide (DMSO) in final assay volume remained $\leq 10 \%$ ( $\mathrm{hA}_{1} \mathrm{AR}$ and $\mathrm{hA_{2A }}$ AR assay) and $\leq 1 \%$ in the $\mathrm{hA}_{3} \mathrm{AR}$ assay. Nonspecific binding was determined using $1 \mu \mathrm{M}$ DPCPX (hA $\mathrm{R}$ assay), $1 \mu \mathrm{M} \mathrm{SCH}-442,416\left(\mathrm{hA}_{2 \mathrm{~A}} \mathrm{R}\right.$ assay), or $10 \mu \mathrm{M}$ I-AB-MECA ( $\mathrm{hA}_{3} \mathrm{AR}$ assay). Filtration through $\mathrm{GF} / \mathrm{B}$ filters (Whatman ${ }^{\circledR}$, presoaked in $0.1 \%$ PEI or $0.5 \%$ BSA) was performed using a cell harvester (Bran$\left.\mathrm{del}^{\circledR}\right)$, and receptor-bound radioactivity was determined via gamma counting (2480 Wizard $^{2}$, PerkinElmer) or liquid scintillation counting (Hidex $300 \mathrm{SL}$ ). $\mathrm{IC}_{50}$ fitted binding curves were generated using the GraphPad Software 5.0, and $K_{i}$ values were calculated using the Cheng-Prusoff equation.

2.2.2. Flow Cytometry. For the flow cytometric evaluation of $\mathrm{hA}_{3} \mathrm{AR}$ expression, single-cell suspensions of HT-29 cells $\left(2 \times 10^{5}\right.$ per tube) were fixed and permeabilized using Cytofix/Cytoperm ${ }^{\mathrm{TM}}$ kit (BD Biosciences). Cells were incubated with mouse monoclonal anti-human $\mathrm{A}_{3} \mathrm{AR}(100 \mu \mathrm{L}$ of $4 \mu \mathrm{g} / \mathrm{mL}$ in PBS + 2\% FCS, Abnova H00000140-M01) or mouse IgG2b kappa isotype control $(100 \mu \mathrm{L}$ of $4 \mu \mathrm{g} / \mathrm{mL}$ in PBS $+2 \%$ FCS, eBioscience $\left.{ }^{\mathrm{TM}} 14-4732-85\right)$ for $1 \mathrm{~h}$ at $4^{\circ} \mathrm{C}$. Following a washing step, bound primary antibodies were detected with rabbit anti-mouse IgG FITC $(100 \mu \mathrm{L}$ of $40 \mu \mathrm{g} / \mathrm{mL}$ in PBS $+2 \%$ FCS, Dako F0261) for $30 \mathrm{~min}$ at $4^{\circ} \mathrm{C}$ in the dark. Samples were analyzed on a FACSCalibur ${ }^{\mathrm{TM}}$ flow cytometer (BD Bioscience), whereby 10,000 single cells were recorded.
2.2.3. Western Blot. Cell lysates were prepared from $75 \mathrm{~cm}^{2}$ cell culture flasks when cells reached $80 \%$ confluency using radioimmunoprecipitation assay (RIPA) buffer and protease inhibitor cocktail according to the manufacturer's instructions. Tissue lysates from HT-29 xenografts were prepared according to a standard protocol using RIPA buffer (according to sample size approx. 4 times of lysis buffer), protease inhibitor, and Ultra-Turrax ${ }^{\circledR}$ for homogenization. The protein concentration of cell lysates was determined using Pierce ${ }^{\mathrm{TM}}$ BCA Protein Assay Kit (Thermo Scientific), and $20 \mu$ g protein per well was loaded onto $\mathrm{TGX}^{\mathrm{TM}}$ precast gels (Bio-Rad). After gel electrophoresis (200 V, $30 \mathrm{~min})$, proteins were transferred to nitrocellulose membranes (Amersham ${ }^{\mathrm{TM}}$ Protran $^{\mathrm{TM}}$ Premium $0.2 \mu \mathrm{m}$ NC, GE Healthcare Life Sciences) via semidry blotting ( $80 \mathrm{~mA}$ per gel). Membranes were incubated with rabbit polyclonal anti- $\mathrm{A}_{3} \mathrm{AR}$ (Santa Cruz Biotechnology, Inc. sc-13938) (1:750, $2 \mathrm{~h}, \mathrm{RT})$ and further incubated with goat anti-rabbit IgG HRP conjugate $(1: 5000,1 \mathrm{~h}, \mathrm{RT})$. Detection was performed using the dedicated kit (SuperSignal West Pico Chemiluminescent Substrate detection kit, Thermo Scientific), and chemiluminescence imaging was conducted (Bio-Rad VersaDoc ${ }^{\mathrm{TM}}$ Imaging System).

\subsection{In Vitro Imaging}

2.3.1. Immunofluorescence Microscopy. HT-29 cells were seeded on chamber slides $\left(3 \times 10^{5} / \mathrm{mL}, 200 \mu \mathrm{L}\right.$ per well, 8 well slides) and incubated at $37^{\circ} \mathrm{C}$ until $50 \%$ confluency was reached. Cells were then fixed ( $4 \%$ paraformaldehyde in PBS, $\left.15 \mathrm{~min}, 4^{\circ} \mathrm{C}\right)$, permeabilized $(0.2 \%$ Triton $\mathrm{X}$ in PBS, $2 \mathrm{~min}$, room temperature (RT)), and blocked ( $2 \%$ FCS in PBS, $30 \mathrm{~min}, \mathrm{RT}$ ). Mouse monoclonal anti-human $\mathrm{A}_{3} \mathrm{AR}$ (Abnova H00000140-M01) and mouse IgG2b kappa isotype control (eBioscience 14-4732-85) were used 1:50 in PBS + $2 \%$ FCS and incubated for $1 \mathrm{~h}$ at RT. Cells were washed three times with PBS and incubated with the secondary antibody (rabbit anti-mouse IgG FITC, Dako F0261) for $1 \mathrm{~h}$ at RT. After washing, cells were incubated with DAPI (1:5000) for $10 \mathrm{~min}$ at RT, and subsequently, slides were embedded with an aqueous mounting medium (Fluoromount ${ }^{\mathrm{TM}}$, Sigma F4680). Slides were recorded on an Axioplan II fluorescence microscope (Carl Zeiss Microscopy).

2.3.2. Autoradiography. Tissue slices were thawed and reconstituted in assay buffer $(50 \mathrm{mM}$ Tris- $\mathrm{HCl} \mathrm{pH} 7.4$, $100 \mathrm{mM} \mathrm{NaCl}, 1 \mathrm{mM}$ EDTA, 1\% BSA, 1 unit adenosine deaminase $/ 100 \mathrm{~mL}$ ) for $30 \mathrm{~min}$ at RT. Radiosynthesis of $\left[{ }^{18} \mathrm{~F}\right]$ FE@SUPPY was performed as previously described and the product was physiologically formulated (EtOH/0.9\% saline 10/90) [20]. Tissue slices were incubated with $50 \mathrm{kBq}$ $\left[{ }^{18} \mathrm{~F}\right] \mathrm{FE} @ S U P P Y(40-200 \mathrm{GBq} / \mu \mathrm{mol})$ in $100 \mu \mathrm{L}$ assay buffer for $1 \mathrm{~h}$ at RT. Slices were thoroughly washed with ice-cold wash buffer (50 mM Tris- $\mathrm{HCl} \mathrm{pH} \mathrm{7.4),} \mathrm{dried,} \mathrm{and} \mathrm{exposed} \mathrm{to}$ a phosphor screen overnight. The readout of the phosphor storage screen was performed on a Cyclone Phosphor Imager (Perkin Elmer), and data analysis was performed using OptiQuant ${ }^{\circledR}$ Software as previously described [26]. Statistical testing was performed using GraphPad Prism 5.0 Software. Differences among groups (colorectal cancer 
versus healthy colon) were analyzed using a two-tailed, unpaired Student's $t$-test with Welch's correction.

2.3.3. Immunohistochemistry. Vicinal cryosections of colorectal carcinoma and healthy colon tissue were stained to identify regions with $\mathrm{hA}_{3} \mathrm{AR}$ expression following a standard protocol. In brief, cryosections were fixed $(96 \%$ ethanol, $10 \mathrm{~min})$, permeabilized ( $0.2 \%$ Triton X-100 in PBS, $5 \mathrm{~min}$ ), and blocked using Bloxall ${ }^{\mathrm{TM}}$ Blocking Solution and a dedicated avidin/biotin blocking kit (Invitrogen, Thermo Fisher Scientific). Additionally, sections were incubated with goat serum (1:10 in PBS) to reduce nonspecific binding. Rabbit polyclonal anti-A AR (1:100, ab203298; Abcam) was used 1:100 in PBS $+0.1 \%$ BSA for $1 \mathrm{~h}$ in a humid, dark chamber. Purified rabbit IgG (Life technologies) was used as an isotype control likewise. Cryosections were washed 3 times for $5 \mathrm{~min}$ (PBS $+0.1 \%$ Tween-20) and incubated with biotinylated anti-rabbit IgG (1:200, PBS $+5 \%$ goat serum) for $30 \mathrm{~min}$. After washing, further detection was performed with the Vectastain ${ }^{\circledR}$ ABC kit (Vector Laboratories) according to the manufacturer's instructions. DAB substrate kit (Abcam) was used as a chromogen to detect peroxidase, and haematoxylin was used for counterstaining of cell nuclei. Immunohistochemically stained slides were acquired on an automated TissueFAXS microscope system (TissueGnostics, Vienna, Austria) at a 5-fold and 20-fold magnification.

\subsection{Tracer Stability in Mice}

2.4.1. In Vitro Stability Tests. Stability of $\left[{ }^{18} \mathrm{~F}\right] \mathrm{FE} @ S U P P Y$ was tested against mouse liver microsomes, mouse S9 fraction, and mouse plasma (BD Sciences). Amount of intact tracer (\%) was determined after 5, 10, 20, 40, 60, and $120 \mathrm{~min}$ using an Agilent series 1100/1200 HPLC system connected to a radioactivity detector (Raytest, Ramona Star) ( $n=2$ in triplicate). The assay was conducted as previously described for respective rat and human enzymes [27].

2.4.2. Ex Vivo Blood Stability. Radiosynthesis was performed as described elsewhere [20] and the product was processed as follows: ethanol was totally evaporated and the dry product was again physiologically formulated in 1.5-2 mL Tween$20 / \mathrm{EtOH} / 0.9 \%$ saline $1 / 9 / 90$ to obtain activity concentrations of approximately $1 \mathrm{GBq} / \mathrm{mL}$. Healthy $\mathrm{BALB} / \mathrm{c}$ mice were injected with $18 \pm 2 \mathrm{MBq}$ (molar activity $=70-200 \mathrm{GBq} / \mu \mathrm{mol}$ ) retroorbitally and sacrificed after $5,10,20,40$, and $70 \mathrm{~min}$ ( $n=3$ for each time point). Blood samples were collected and immediately precipitated using acetonitrile/methanol $(10: 1)$ and centrifuged $\left(12,000 \mathrm{rpm}, 5 \mathrm{~min}, 4^{\circ} \mathrm{C}\right)$. The obtained supernatants were subjected to radio-HPLC as previously described [22].

2.5. Biodistribution. Ex vivo biodistribution of $\left[{ }^{18} \mathrm{~F}\right]$ FE@SUPPY was assessed $70 \mathrm{~min}$ after tracer application in BALB/c mice. Radioactivity was determined using a gamma counter (2480 Wizard $^{2}$, PerkinElmer), organs were wet-weighted, and percentage of injected dose per gram of organ was calculated (\%ID/g).
2.6. In Vivo Imaging. Xenograft-bearing CB17-SCID mice were anesthetized using isoflurane $(2.5 \%)$ mixed with oxygen $(1.5 \mathrm{~L} / \mathrm{min})$ to avoid movement during the imaging. Blocking agents (2 mg/kg BW FE@SUPPY or MRS1523) or the respective vehicle control (Tween-20/EtOH/0.9\% physiological saline 1/9/90) was administered retroorbitally 2 min prior to the radiotracer administration ( $n=3$ per group). Subsequently, the animals received another retroorbital injection of $17.42 \pm 4.5 \mathrm{MBq}\left[{ }^{18} \mathrm{~F}\right] \mathrm{FE} @ S U P P Y$ into the venous plexus of the opposite eye. With a minor delay after the application of the radiotracer (2-3 min), mice were placed into the field of view of the scanner $(\mu \mathrm{PET} / \mathrm{CT}$ Inveon, Siemens Medical Solution, Knoxville, USA), and dynamic imaging was performed for $60 \mathrm{~min}$ to follow tracer distribution. Vital parameters (respiration, body temperature) were continuously monitored using a dedicated monitoring unit (bioVet; $\mathrm{m} 2 \mathrm{~m}$ imaging, Cleveland, $\mathrm{OH}$, USA) to ensure the depth of anesthesia and wellbeing of the animals. Retroorbital application volumes did not exceed $100 \mu \mathrm{L}$ per application.

\section{Results and Discussion}

3.1. Characterization of Binding and Target Expression. Affinity and selectivity of FE@SUPPY and its potential metabolites upon cleavage by carboxylesterases, DFE@SUPPY, and FE@SUPPY:11 [28] were determined in competitive binding assays. FE@SUPPY has been first described by Li et al., who reported a $K_{i}$ value of $4.22 \pm 0.7 \mathrm{nM}$ for human $\mathrm{A}_{3} \mathrm{AR}$. However, this study only provided the selectivity ratio towards rat $\mathrm{A}_{1} \mathrm{AR}\left(\mathrm{rA}_{1} \mathrm{AR} / \mathrm{hA} \mathrm{A}_{3} \mathrm{AR}=7400\right)$ [29]. Here, we confirmed the affinity of FE@SUPPY towards the human $\mathrm{A}_{3} \mathrm{AR}\left(K_{i}\right.$ $=6.02 \pm 0.4 \mathrm{nM}, n=3$ ) and demonstrated its selective $\mathrm{hA}_{3} \mathrm{AR}$ binding compared to the other human adenosine receptors. Moreover, the respective theoretical metabolites show little affinity for the $\mathrm{hA}_{3} \mathrm{AR}$, supporting the potential of FE@SUPPY as a ligand for human in vivo application (Table 1).

The human colorectal adenocarcinoma cell line (HT-29) was characterized regarding its $\mathrm{hA}_{3} \mathrm{AR}$ protein expression using flow cytometry and western blot. Flow cytometric analysis resulted in mean fluorescence intensity $(\triangle \mathrm{MFI})$ of $53.6 \pm 22$ in three independent experiments (Figure 1). Additionally, $\mathrm{A}_{3} \mathrm{AR}$ protein expression in HT-29 cells was determined by western blot (Figure 8) (western blot results are discussed separately below). This is in line with previous studies, which reported $\mathrm{A}_{3} \mathrm{AR}$ expression for this cell line as well $[13,15]$. Thus, HT-29 cells were subsequently chosen for tumor graft experiments.

3.2. In Vitro Imaging. Fluorescence microscopy of HT-29 cells showed cell membrane-specific staining, pointing at the expression of $\mathrm{hA}_{3} \mathrm{AR}$ on the cell surface, which is typical for GPCRs (Figure 2).

In all investigated regions of the two CRC patients, $\left[{ }^{18} \mathrm{~F}\right] \mathrm{FE} @ S U P P Y$ accumulation was higher in colorectal carcinoma tissue slices than in healthy colon tissue slices of the same individual (for detailed analysis see supplementary (available here)). In 5 of 7 regions, $a \geq 2.3$-fold higher binding 
TABLE 1: Affinity and selectivity data of FE@SUPPY and metabolites towards adenosine receptor subtypes $(n=3-5$ in triplicate; amount of DMSO never exceeded $1 \%$ of total assay volume in $\mathrm{hA}_{3} \mathrm{AR}$ assay; DMSO was added up to $10 \%$ in $\mathrm{hA_{1 }} \mathrm{AR}_{\text {and }} \mathrm{hA} \mathrm{A}_{2 \mathrm{~A}} \mathrm{AR}$ assay; ${ }^{*} n=2$ in triplicate; exact $K_{i}$ value could not be determined due to limited solubility).

\begin{tabular}{|c|c|c|c|c|c|}
\hline Compound & $\mathrm{hA}_{1} \mathrm{AR}$ & $\mathrm{hA}_{2 \mathrm{~A}} \mathrm{AR}$ & $\mathrm{hA}_{3} \mathrm{AR}$ & $\mathrm{hA}_{1} / \mathrm{hA}_{3} \mathrm{AR}$ & $\mathrm{hA}_{2 \mathrm{~A}} / \mathrm{hA}_{3} \mathrm{AR}$ \\
\hline FE@SUPPY & $4.03 \pm 1.0 \mu \mathrm{M}$ & $1.72 \pm 0.4 \mu \mathrm{M}$ & $6.02 \pm 0.4 \mathrm{nM}$ & 669 & 285 \\
\hline DFE@SUPPY & $5.46 \pm 0.4 \mu \mathrm{M}$ & $37.13 \pm 16 \mu \mathrm{M}$ & $2.58 \pm 1.2 \mu \mathrm{M}$ & 324 & 112 \\
\hline FE@SUPPY:11 & $\geq 57 \mu \mathrm{M}^{*}$ & $5.86 \pm 0.8 \mu \mathrm{M}$ & $2.80 \pm 1.4 \mu \mathrm{M}$ & $\geq 20$ & 2 \\
\hline
\end{tabular}

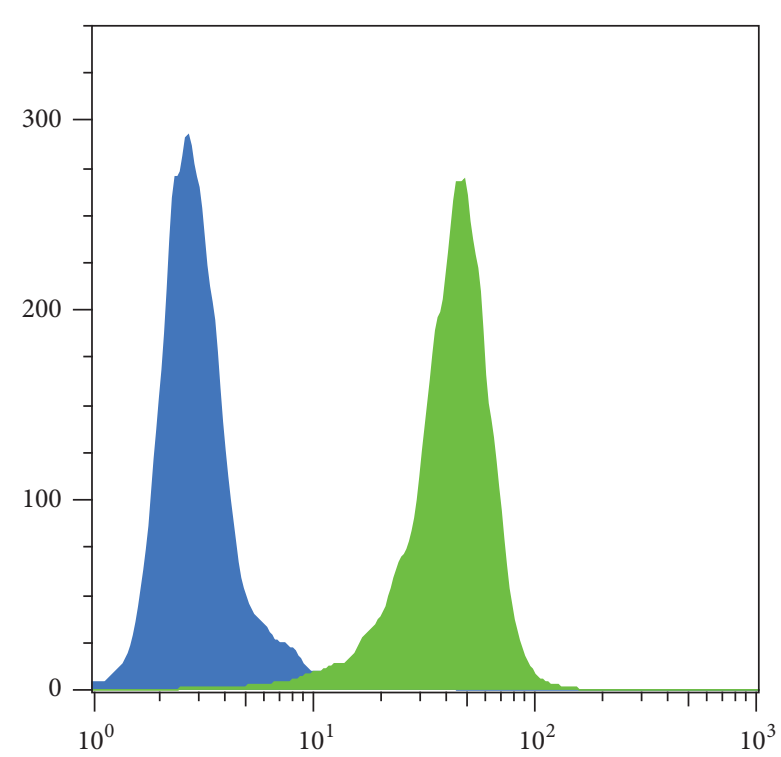

FIGURE 1: Flow cytometric analysis of HT-29 cells revealed expression of $\mathrm{hA}_{3} \mathrm{AR}$ protein (green). The isotype control did not show fluorescence signal (blue).

of $\left[{ }^{18} \mathrm{~F}\right] \mathrm{FE} @ S U P P Y$ was found $(P<0.05)$. This finding is in accordance with Gessi et al., who reported similar ratios by means of $\left[{ }^{3} \mathrm{H}\right]$ MRE 3008F20 binding [18]. Regions with high accumulation of $\left[{ }^{18} \mathrm{~F}\right] \mathrm{FE} @ S U P P Y$ corresponded to regions with high $\mathrm{hA}_{3} \mathrm{AR}$ expression identified by immunohistochemistry (Figure 3).

3.3. Tracer Stability in Mice. $\left[{ }^{18} \mathrm{~F}\right] \mathrm{FE} @ S U P P Y$ exhibited high stability in mouse plasma, as $92.6 \pm 0.7 \%$ of intact tracer could still be detected after $120 \mathrm{~min}$ of incubation at $37^{\circ} \mathrm{C}$. In vitro stability tests against mouse liver homogenates ( $\mathrm{S} 9$ fraction) and purified mouse liver microsomes showed $66.9 \pm 6.7 \%$ and $31.4 \pm 7.8 \%$ intact tracer after $120 \mathrm{~min}$, respectively. Ex vivo blood stability analysis demonstrated more rapid degradation of $\left[{ }^{18} \mathrm{~F}\right] \mathrm{FE} @ S U P P Y$ in vivo than that observed in in vitro testing as only $2.2 \pm 0.4 \%$ intact $\left[{ }^{18} \mathrm{~F}\right] \mathrm{FE} @ S U P P Y$ could be determined after $70 \mathrm{~min}$ (Figure 4). This data indicates higher metabolism in mice compared to rats described in previously conducted studies, where $25.8 \pm 5.3 \%$ intact tracer was found in plasma after $60 \mathrm{~min}$ [22]. However, these data could also be mimicked by the fact that intact $\left[{ }^{18} \mathrm{~F}\right] \mathrm{FE} @ S U P P Y$ is rapidly cleared from blood hepatobiliary (into the bile fluid, compare
Figures 5 and 7), and the equilibrium in blood is therefore shifted to the metabolites.

3.4. Biodistribution. Biodistribution was assessed $70 \mathrm{~min}$ after tracer application in healthy $\mathrm{BALB} / \mathrm{c}$ mice and revealed a high accumulation of radioactivity in fat-rich regions (brown adipose tissue, BAT) likely due to the tracer's lipophilicity [30]. Regarding the emunctory organs, liver showed the highest accumulation $(14.57 \pm 0.20 \% \mathrm{ID} / \mathrm{g})$, followed by the kidneys $(2.67 \pm 0.24 \% \mathrm{ID} / \mathrm{g})$. The additional analysis of body liquids pointed at a mainly hepatobiliary excretion of $\left[{ }^{18} \mathrm{~F}\right]$ FE@SUPPY, as the highest amount was found in bile fluid $(162.78 \pm 37.51 \% \mathrm{ID} / \mathrm{g})$. The amount of radioactivity in the kidneys and urine $(43.33 \pm 9.23 \% \mathrm{ID} / \mathrm{g})$ suggests the excretion of the hydrophilic radioactive metabolite, 2$\left[{ }^{18} \mathrm{~F}\right]$ fluoroethanol [31], which was already proposed by Haeusler et al. [28]. The circulating radioactivity in blood was low after $70 \mathrm{~min}(1.6 \pm 0.1 \% \mathrm{ID} / \mathrm{g})$. This finding is in accordance with the results obtained by the ex vivo blood analysis. Moreover, pronounced accumulation of $\left[{ }^{18} \mathrm{~F}\right] \mathrm{FE} @ S U P P Y$ was found in $\mathrm{A}_{3} \mathrm{AR}$ rich tissues such as the heart $(1.13 \pm 0.04 \%$ $\mathrm{ID} / \mathrm{g})$ and lung $(1.50 \pm 0.23 \% \mathrm{ID} / \mathrm{g})$. A similar biodistribution pattern was observed for rats in a previously conducted study [20]. $\left[{ }^{18} \mathrm{~F}\right] \mathrm{FE} @ S U P P Y$ accumulation in the brain was low after $70 \mathrm{~min}(0.23 \pm 0.03 \% \mathrm{ID} / \mathrm{g})$ (Figure 5$)$.

3.5. In Vivo Imaging. $\mu \mathrm{PET}$ imaging of the mouse xenograft model revealed high uptake of $\left[{ }^{18} \mathrm{~F}\right] \mathrm{FE} @ S U P P Y$ in the emunctory organs, which was again most pronounced in the liver (SUV $=6.68 \pm 0.80)$. Low standardized uptake values were observed in tumor masses of both HT-29 and $\mathrm{CHO}-\mathrm{K} 1$ xenograft tumors (SUV $=0.23 \pm 0.06$ and $0.25 \pm$ 0.33 ), respectively. There was no difference between $\mathrm{CHO}-$ $\mathrm{K} 1$ xenografts, which served as a negative control (human $\mathrm{A}_{3}$ AR negative), and HT-29 xenografts. Moreover, significant blocking could not be achieved (Figure 6). The affinity of FE@SUPPY for the mouse $\mathrm{A}_{3} \mathrm{AR}$ is uncertain but is expected to be lower than that for the human $\mathrm{A}_{3} \mathrm{AR}$ due to the known species differences. The lack of adequate rodent models, mainly due to the low affinity of most $\mathrm{hA}_{3} \mathrm{AR}$ ligands to the rodent $\mathrm{A}_{3} \mathrm{AR}$, was already recognized by Yamano et al. who proposed a humanized mouse model [32]. Specific uptake was therefore not expected in mouse tissues. Interestingly, a significant influence of the blocking was observed in BAT (decrease in uptake) and lung (increase in uptake). However, the data is based on a set of three individuals in each group, and displacement was not performed in the same individuals. 

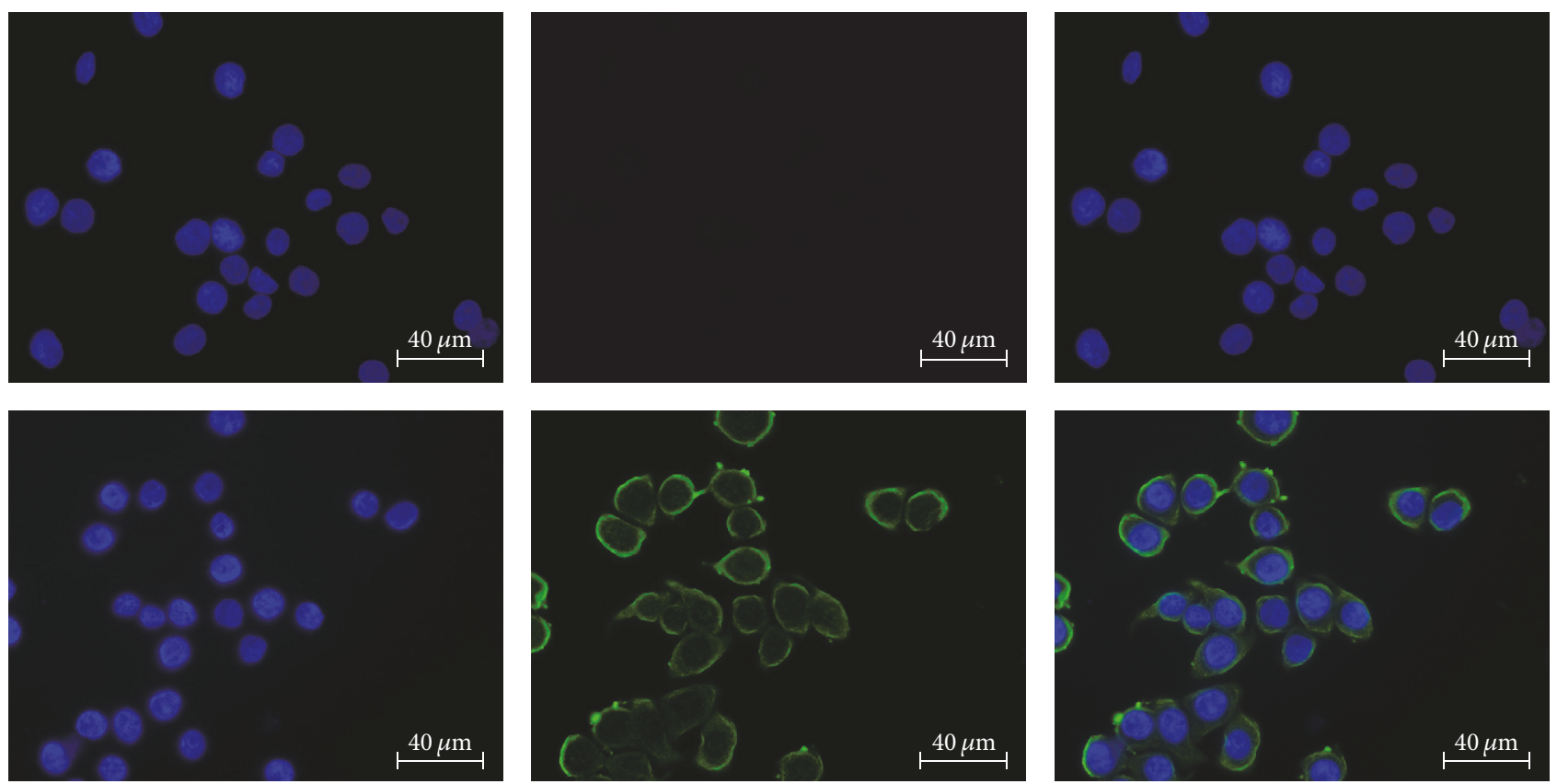

FIGURE 2: Immunofluorescent staining of HT-29 cells; left: DAPI, middle: FITC, right: merge. Upper row: mouse isotype control, lower row: anti-human $\mathrm{A}_{3} \mathrm{AR}$ staining.
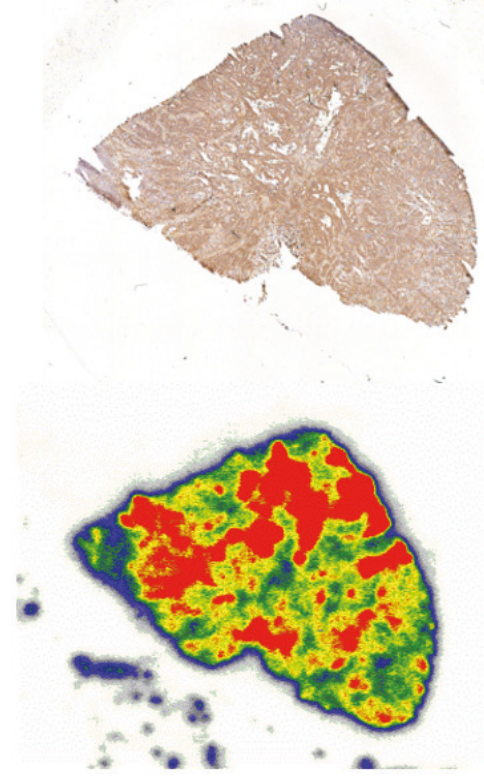
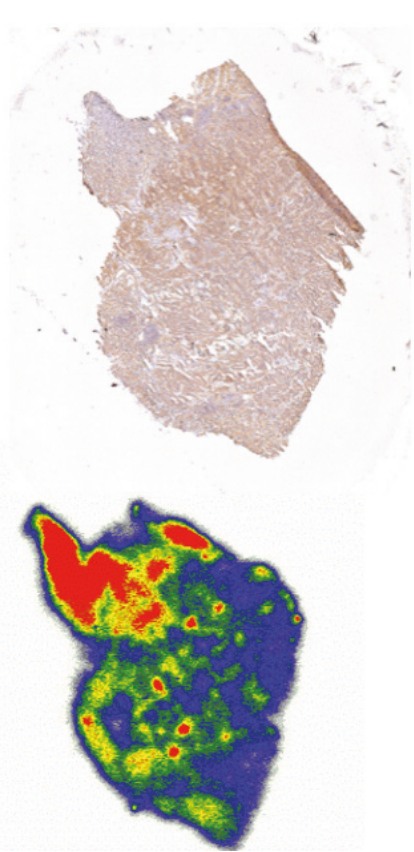
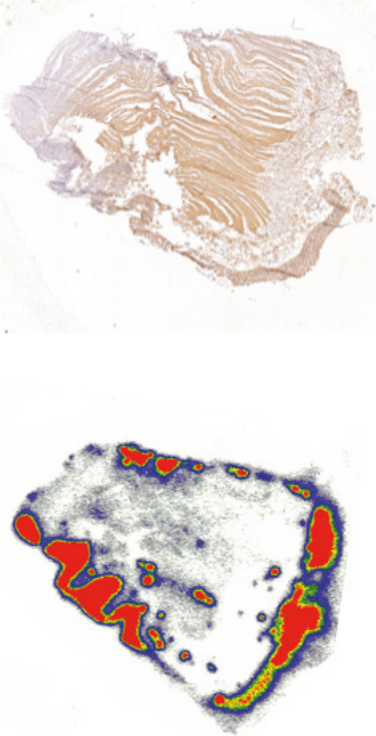

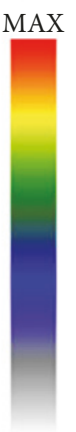

MIN

FIGURE 3: Upper row: immunohistochemical staining of $h \mathrm{~A}_{3} \mathrm{AR}$. Lower row: autoradiographic analysis of the corresponding vicinal tissue slices using $\left[{ }^{18} \mathrm{~F}\right] \mathrm{FE} @ S U P P Y$. Left and center: colon cancer tissue, right: healthy colon tissue.

Since tumor uptake in the chosen model was insufficient and not blockable, this phenomenon was not investigated any further.

For a detailed analysis of the pharmacokinetics, volumes of interest were also generated for mouse body liquids including blood, urine, and bile fluid (Figure 7). The radioactivity in blood was generally low (SUV $=1.21 \pm 0.11)$ compared to the body liquids, urine ( $\mathrm{SUV}=8.86 \pm 3.44$ ), and bile fluid $(21.85 \pm 10.63)$, showing the highest accumulation of $\left[{ }^{18} \mathrm{~F}\right] \mathrm{FE} @ S U P P Y$, which is in line with the biodistribution experiments. The mentioned standardized uptake values refer to baseline conditions. 


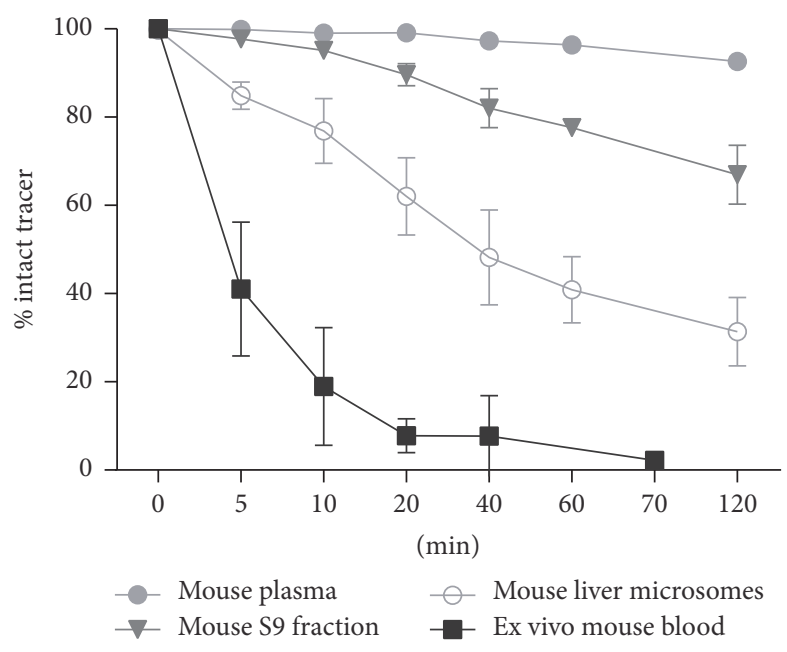

FIGURE 4: In vitro stability and ex vivo blood stability of $\left[{ }^{18} \mathrm{~F}\right] \mathrm{FE} @ S U P P Y$.

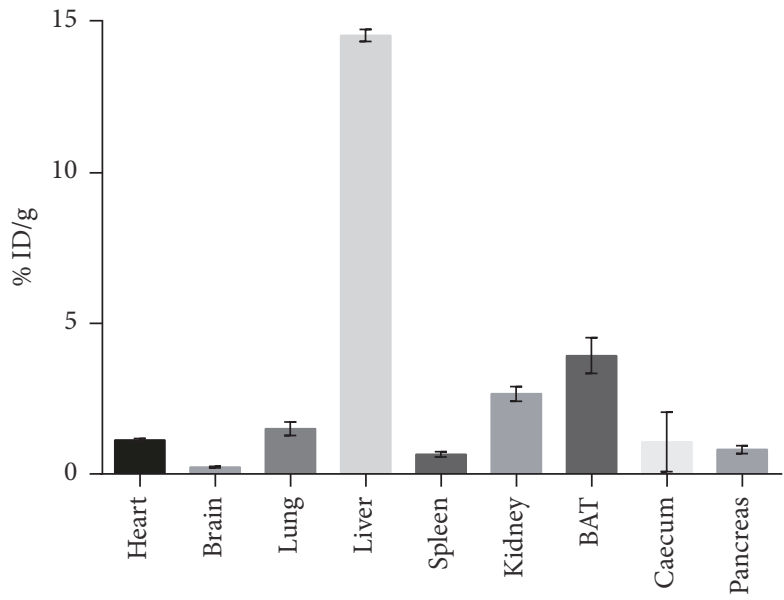

(a)

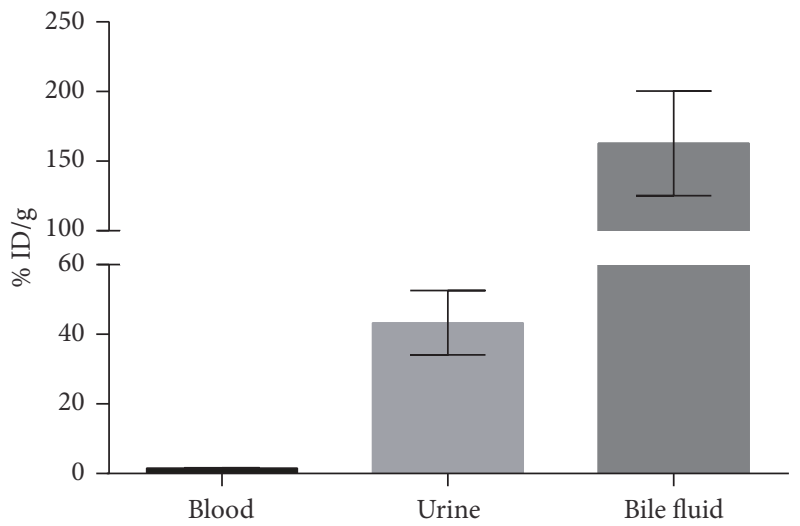

(b)

FIGURE 5: Biodistribution of $\left[{ }^{18} \mathrm{~F}\right] \mathrm{FE} @ S U P P Y$ in healthy BALB/c mice $(n=3)$. (a) shows biodistribution in organs. (b) shows accumulation in body liquids.

Adenosine concentrations of $\sim 0,5 \mu \mathrm{M}$ have been proposed in HT-29 tumors grown as xenografts [4]. Even though adenosine displays only intermediate affinity for the $\mathrm{A}_{3} \mathrm{AR}$ $\left(\sim 1 \mu \mathrm{M}\right.$ at the rat $\mathrm{A}_{3} \mathrm{AR}$ [33]), the PET-tracer would have to compete with the endogenous ligand for $\mathrm{A}_{3} \mathrm{AR}$ occupancy. This may decrease accumulation of $\left[{ }^{18} \mathrm{~F}\right] \mathrm{FE} @ S U P P Y$ in the xenografts. However, more importantly, despite the fact that western blot analysis demonstrated $\mathrm{hA}_{3} \mathrm{AR}$ expression in HT-29 cells, $\mathrm{hA}_{3} \mathrm{AR}$ protein could not be detected in tissue lysates derived from HT-29 xenografts. This indicates that the human receptor is poorly conserved in mice upon tumor graft (Figure 8). To our knowledge, this phenomenon has not been described in literature so far but has tremendous impact on in vivo imaging. PET imaging is only feasible if an abundant amount of the target is available, as only nanomolar or even lower concentrations of PET-tracers are applied.

\section{Conclusion}

We found a favorable binding profile of $\left[{ }^{18} \mathrm{~F}\right] \mathrm{FE} @ S U P P Y$ displaying high affinity for the human $\mathrm{A}_{3} \mathrm{AR}$ besides low affinity for the other human adenosine receptor subtypes. Autoradiography showed $\geq 2.3$-fold higher uptake in human CRC compared to adjacent healthy colon tissues. First in vivo studies using HT-29 xenografts showed insufficient tumor uptake. After initial high expression rates of the $\mathrm{A}_{3} \mathrm{AR}$ in the HT-29 cells, tumor masses, derived from HT29 xenografts, revealed low target expression. The receptor was not conserved in the xenograft, which hampered the PET imaging strategy. An additional drawback of the used mouse model is the unfavorable pharmacokinetics of the PET-tracer $\left[{ }^{18} \mathrm{~F}\right] \mathrm{FE} @ S U P P Y$ in mice. It is questionable how accurate xenograft models in immunocompromised mice are to study the role of human $\mathrm{A}_{3} \mathrm{ARs}$ in cancer. Despite all efforts, in vivo 


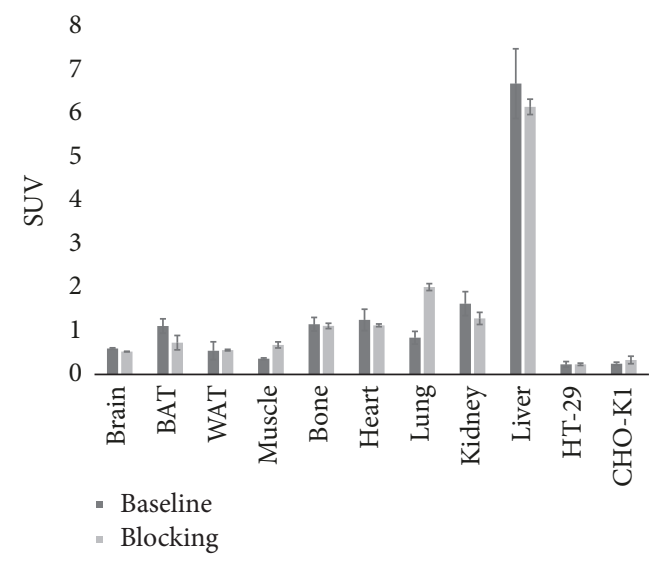

FIGURE 6: $\mu$ PET-imaging was performed for $60 \mathrm{~min}$. Activity concentration of $\left[{ }^{18} \mathrm{~F}\right] \mathrm{FE} @ S U P P Y$ in organs of interest is expressed as standardized uptake value (SUV). Blocking experiments, shown in the figure, were performed using unlabeled FE@SUPPY. Blocking experiments using MRS1523 provided the same outcome and are not shown in the figure.

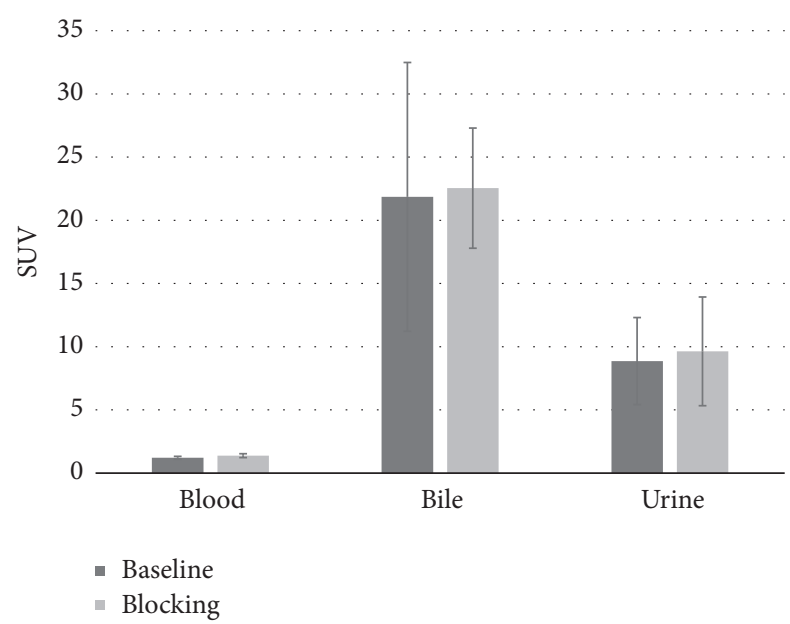

Figure 7: $\mu$ PET-imaging was performed for $60 \mathrm{~min}$. Activity concentration of $\left[{ }^{18} \mathrm{~F}\right] \mathrm{FE} @ S U P P Y$ in body liquids is expressed as standardized uptake value (SUV). Blocking experiments, shown in the figure, were performed using unlabeled FE@SUPPY. Blocking experiments using MRS1523 provided the same outcome and are not shown in the figure.

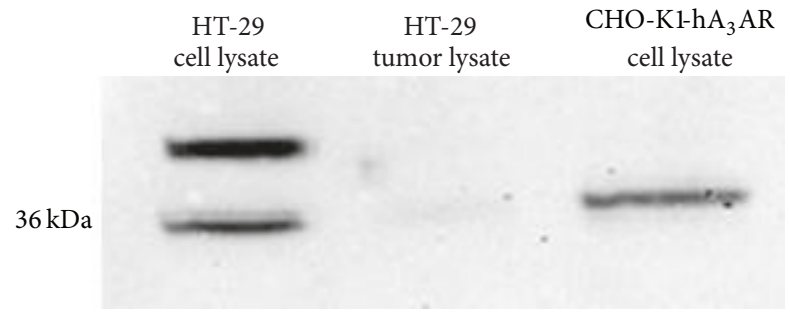

FIgURE 8: Western blot analysis of HT-29 cell lysate and tissue lysate derived from HT-29 xenograft tumors. CHO-K1-hA ${ }_{3}$ AR cell lysate was loaded as a positive control. An additional bond of unknown identity was detected in HT-29 cell lysate. visualization of the $A_{3} A R$ has not been successful to date and deeper understanding of $A_{3} A R$ function is still missing.

\section{Conflicts of Interest}

The authors declare that they have no conflicts of interest.

\section{Acknowledgments}

This work was supported by the Austrian Science Fund (FWF P26502-B24, M. Mitterhauser) and was performed with the support of the Molecular Imaging Cluster of the Medical University of Vienna, Austria. J. Fazekas-Singer was supported by Grant CCHD W1205-B09 awarded to Dr. E. Jensen-Jarolim. The authors want to thank Petra Fürlinger for her collaboration in the autoradiography experiments and Markus Zeilinger for his support in statistics.

\section{Supplementary Materials}

Table S1: binding values of FE@SUPPY are expressed as $\mathrm{fmol} / \mathrm{mm}^{2}$ tissue. (Supplementary Materials)

\section{References}

[1] Global Burden of Disease Cancer C, "The global burden of cancer 2013," JAMA Oncology, vol. 1, no. 4, pp. 505-527, 2015.

[2] L. Fass, "Imaging and cancer: a review," Molecular Oncology, vol. 2, no. 2, pp. 115-152, 2008.

[3] B. B. Fredholm, A. P. Ijzerman, K. A. Jacobson, K. Klotz, and J. Linden, "International Union of Pharmacology. XXV. Nomenclature and classification of adenosine receptors," Pharmacological Reviews, vol. 53, no. 4, pp. 527-552, 2001.

[4] J. Blay, T. D. White, and D. W. Hoskin, "The extracellular fluid of solid carcinomas contains immunosuppressive concentrations of adenosine," Cancer Research, vol. 57, no. 13, pp. 2602-2605, 1997.

[5] S. Merighi, P. Mirandola, K. Varani et al., "A glance at adenosine receptors: Novel target for antitumor therapy," Pharmacology \& Therapeutics, vol. 100, no. 1, pp. 31-48, 2003.

[6] S. Gessi, S. Merighi, V. Sacchetto, C. Simioni, and P. A. Borea, "Adenosine receptors and cancer," Biochimica et Biophysica Acta (BBA) - Biomembranes, vol. 1808, no. 5, pp. 1400-1412, 2011.

[7] P. A. Borea, S. Gessi, S. Merighi, and K. Varani, "Adenosine as a multi-signalling guardian angel in human diseases: when, where and how does it exert its protective effects?" Trends in Pharmacological Sciences, vol. 37, no. 6, pp. 419-434, 2016.

[8] S. Gessi, K. Varani, S. Merighi et al., "Pharmacological and biochemical characterization of A 3 adenosine receptors in Jurkat T cells," British Journal of Pharmacology, vol. 134, no. 1, pp. 116-126, 2001.

[9] S. Merighi, P. Mirandola, D. Milani et al., "Adenosine receptors as mediators of both cell proliferation and cell death of cultured human melanoma cells," Journal of Investigative Dermatology, vol. 119, no. 4, pp. 923-933, 2002.

[10] S. Merighi, A. Benini, P. Mirandola et al., "A3 adenosine receptors modulate hypoxia-inducible factor- $1 \alpha$ expression in human A375 melanoma cells," Neoplasia, vol. 7, no. 10, pp. 894903, 2005. 
[11] S. Gessi, K. Varani, S. Merighi et al., "A3 adenosine receptors in human neutrophils and promyelocytic HL60 cells: A pharmacological and biochemical study," Molecular Pharmacology, vol. 61, no. 2, pp. 415-424, 2002.

[12] M. L. Trincavelli, D. Tuscano, M. Marroni et al., "A3 adenosine receptors in human astrocytoma cells: Agonist-mediated desensitization, internalization, and down-regulation," Molecular Pharmacology, vol. 62, no. 6, pp. 1373-1384, 2002.

[13] M. Sakowicz-Burkiewicz, A. Kitowska, M. Grden, I. Maciejewska, A. Szutowicz, and T. Pawelczyk, "Differential effect of adenosine receptors on growth of human colon cancer HCT 116 and HT-29 cell lines," Archives of Biochemistry and Biophysics, vol. 533, no. 1-2, pp. 47-54, 2013.

[14] E. Polycarpou, L. B. Meira, S. Carrington, E. Tyrrell, H. Modjtahedi, and M. A. Carew, "Resveratrol 3-O-d-glucuronide and resveratrol $4^{\prime}$-O-d-glucuronide inhibit colon cancer cell growth: evidence for a role of A3 adenosine receptors, cyclin D1 depletion, and G1 cell cycle arrest," Molecular Nutrition \& Food Research, vol. 57, no. 10, pp. 1708-1717, 2013.

[15] S. Gessi, S. Merighi, K. Varani et al., "Adenosine receptors in colon carcinoma tissues and colon tumoral cell lines: focus on the A3 adenosine subtype," Journal of Cellular Physiology, vol. 211, no. 3, pp. 826-836, 2007.

[16] S. Merighi, A. Benini, P. Mirandola et al., "Caffeine inhibits adenosine-induced accumulation of hypoxia-inducible factor$1 \alpha$, vascular endothelial growth factor, and interleukin- 8 expression in hypoxic human colon cancer cells," Molecular Pharmacology, vol. 72, no. 2, pp. 395-406, 2007.

[17] L. Madi, A. Ochaion, L. Rath-Wolfson et al., "The A3 adenosine receptor is highly expressed in tumor versus normal cells: Potential target for tumor growth inhibition," Clinical Cancer Research, vol. 10, no. 13, pp. 4472-4479, 2004.

[18] S. Gessi, E. Cattabriga, A. Avitabile et al., "Elevated expression of A3 adenosine receptors in human colorectal cancer is reflected in peripheral blood cells," Clinical Cancer Research, vol. 10, no. 17, pp. 5895-5901, 2004.

[19] A. Koussounadis, S. P. Langdon, I. H. Um, D. J. Harrison, and V. A. Smith, "Relationship between differentially expressed mRNA and mRNA-protein correlations in a xenograft model system," Scientific Reports, vol. 5, Article ID 10775, 2015.

[20] W. Wadsak, L.-K. Mien, K. Shanab et al., "Preparation and first evaluation of [18F]FE@SUPPY: a new PET tracer for the adenosine A3 receptor," Nuclear Medicine and Biology, vol. 35, no. 1, pp. 61-66, 2008.

[21] W. Wadsak, L.-K. Mien, K. Shanab et al., "Radiosynthesis of the adenosine A3 receptor ligand 5-(2-[ 18F]fluoroethyl) 2,4diethyl-3-(ethylsulfanylcarbonyl)-6- phenylpyridine-5-carboxylate ([18F]FE@SUPPY)," Radiochimica Acta, vol. 96, no. 2, pp. 119-124, 2008.

[22] D. Haeusler, C. Kuntner, L. Nics et al., “[18F]FE@SUPPY: a suitable PET tracer for the adenosine A3 receptor? An in vivo study in rodents," European Journal of Nuclear Medicine and Molecular Imaging, vol. 42, no. 5, pp. 741-749, 2015.

[23] M. Mitterhauser, D. Haeusler, L. Mien et al., "Automatisation and First Evaluation of [18F]FE@SUPPY:2, an Alternative PETTracer for the Adenosine A3 Receptor: A Comparison with [18F]FE@SUPPY," The Open Nuclear Medicine Journal, vol. 1, no. 1, pp. 15-23, 2009.

[24] M. Gao, A. C. Gao, M. Wang, and Q.-H. Zheng, "Simple synthesis of new carbon-11-labeled 1,2,4-triazolo[4,3-a] quinoxalin1-one derivatives for PET imaging of A3 adenosine receptor," Applied Radiation and Isotopes, vol. 91, pp. 71-78, 2014.
[25] D. O. Kiesewetter, L. Lang, Y. Ma et al., "Synthesis and characterization of [76Br]-labeled high-affinity A3 adenosine receptor ligands for positron emission tomography," Nuclear Medicine and Biology, vol. 36, no. 1, pp. 3-10, 2009.

[26] C. Philippe, D. Haeusler, F. Fuchshuber et al., "Comparative autoradiographic in vitro investigation of melanin concentrating hormone receptor 1 ligands in the central nervous system," European Journal of Pharmacology, vol. 735, no. 1, pp. 177-183, 2014.

[27] L. Nics, C. Vraka, M. Hendl, D. Haeusler, K. H. Wagner, K. Shanab et al., "In-vitro stability of [18F]FE@SUPPPY and [18F]FE@SUPPY:2 against human liver-microsomes and human plasma," Nuklearmedizin, vol. 50, 2011.

[28] D. Haeusler, L. Nics, L.-K. Mien et al., "[18F]FE@SUPPY and [18F]FE@SUPPY:2 - metabolic considerations," Nuclear Medicine and Biology, vol. 37, no. 4, pp. 421-426, 2010.

[29] A.-H. Li, S. Moro, N. Forsyth, N. Melman, X.-D. Ji, and K. A. Jacobson, "Synthesis, CoMFA analysis, and receptor docking of 3,5-diacyl-2,4- dialkylpyridine derivatives as selective A3 adenosine receptor antagonists," Journal of Medicinal Chemistry, vol. 42, no. 4, pp. 706-721, 1999.

[30] C. Vraka, L. Nics, K.-H. Wagner, M. Hacker, W. Wadsak, and M. Mitterhauser, “LogP, a yesterday's value?” Nuclear Medicine and Biology, vol. 50, pp. 1-10, 2017.

[31] J. Pan, M. Pourghiasian, N. Hundal et al., "2-[18F]Fluoroethanol and 3-[18F]fluoropropanol: Facile preparation, biodistribution in mice, and their application as nucleophiles in the synthesis of [18F]fluoroalkyl aryl ester and ether PET tracers," Nuclear Medicine and Biology, vol. 40, no. 6, pp. 850-857, 2013.

[32] K. Yamano, M. Inoue, S. Masaki, M. Saki, M. Ichimura, and M. Satoh, "Generation of adenosine A3 receptor functionally humanized mice for the evaluation of the human antagonists," Biochemical Pharmacology, vol. 71, no. 3, pp. 294-306, 2006.

[33] K. A. Jacobson, H. O. Kim, S. M. Siddiqi, M. E. Olah, G. L. Stiles, and D. K. J. E. Von Lubitz, "A3-adenosine receptors: Design of selective ligands and therapeutic prospects," Drugs of the Future, vol. 20, no. 7, pp. 689-699, 1995. 


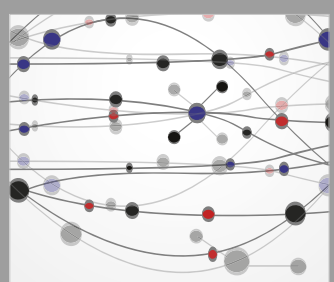

The Scientific World Journal
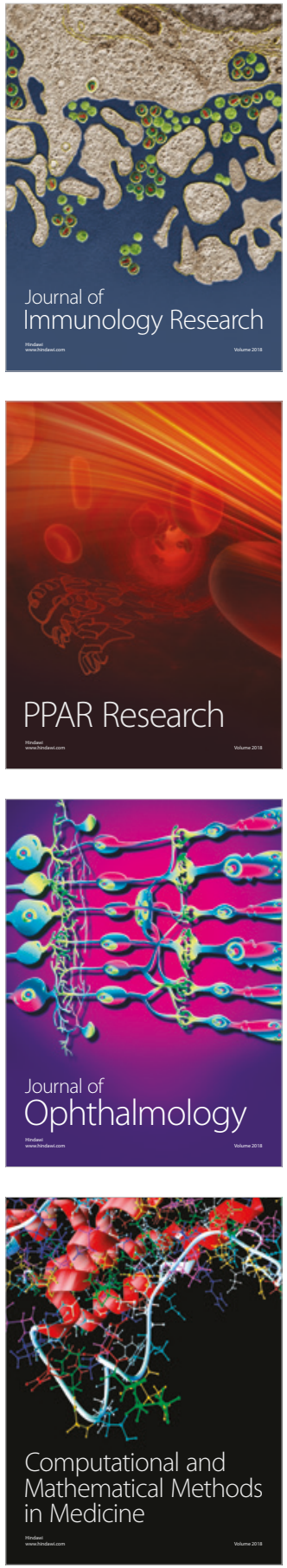

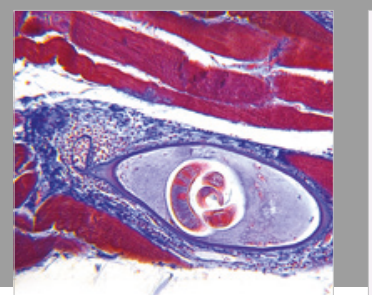

Gastroenterology Research and Practice

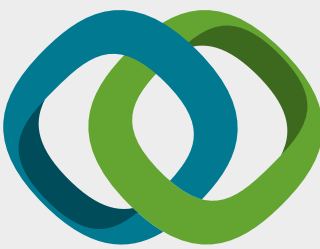

\section{Hindawi}

Submit your manuscripts at

www.hindawi.com
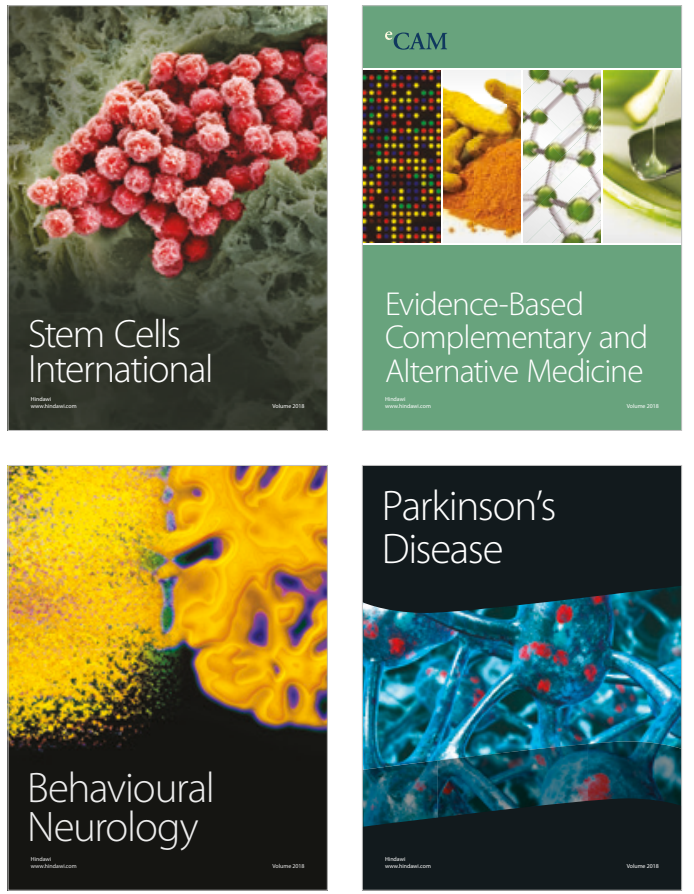

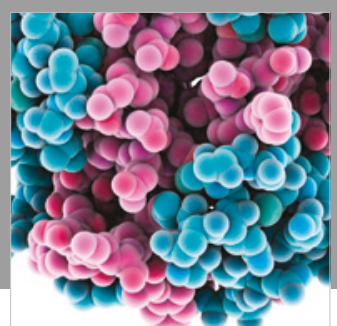

ournal of

Diabetes Research

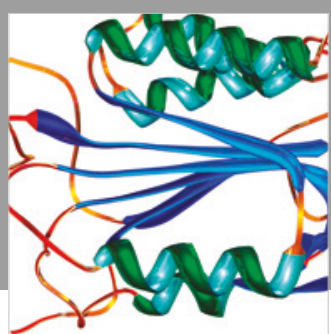

Disease Markers
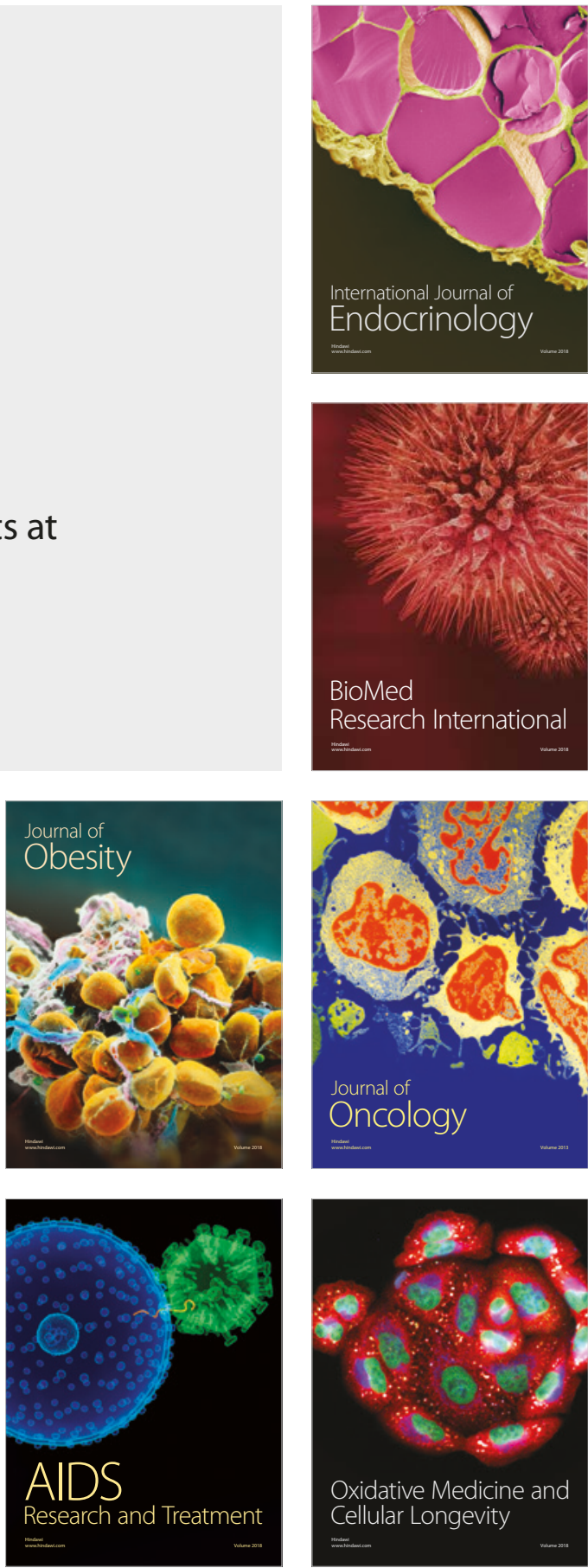